\title{
Some myxomycetes from Dar es Salaam (Tanzania) developed in moist chamber cultures
}

\author{
TARJA UKKOLA
}

\begin{abstract}
UKKOLA, T. 1998: Some myxomycetes from Dar es Salaam (Tanzania) developed in moist chamber cultures. - Karstenia 38: 27-36. Helsinki. ISSN 0435-3402

Nineteen species of myxomycetes are reported from Dar es Salaam, Oyster Bay. The following taxa are new to Tanzania: Licea kleistobolus G. W. Martin, Physarum echinosporum Lister, P. oblatum T. Macbr., and P. spumarioides T. N. Lakh. \& Mukerji var. degawae Nann.-Bremek. \& Y. Yamam., the latter taxon being reported from Africa for the first time. A species of Licea is described with illustrations, but not named, as the material existing is fairly scanty. A total of 27 specimens of seven genera are presented, all developed in moist chamber cultures on bark from living trees or on plant remains.
\end{abstract}

Key words: Africa, Dar es Salaam, moist chamber culture, Myxomycetes, Tanzania

Tarja Ukkola, Department of Ecology and Systematics, P.O. Box 47, FIN-00014 University of Helsinki, Finland

\section{Introduction}

This study is a further contribution to a series of studies dealing with the diversity of myxomycetes in Tanzania, East Africa. Earlier studies are by Härkönen and Saarimäki (1991), Ukkola and Härkönen (1996), and Ukkola, Härkönen and Saarimäki (1996). Before these studies, the myxomycetes of Tanzania had been studied only at the beginning of the century by a German researcher, F. Eichelbaum (1906), who reported 16 species from the East Usambara mountains.

I was a member of a group of researchers from the University of Helsinki, Finland, who in December 1995 made a field trip to the Usambara mountains in NE Tanzania. On our way to the Usambaras we spent a few days in Dar es Salaam. Dar es Salaam is located in the Eastern Province (Polhill 1988) on the coast of the Indian Ocean, and the climate is tropical. The mean annual rainfall is $1060 \mathrm{~mm}$, statistically there are eight rainy days, and the mean precipitation is $95 \mathrm{~mm}$ in Dar es Salaam in December. However, during our stay, there was no rain and no fruit bodies of myxomycetes were found. The mean temperature in December during the daytime is $32{ }^{\circ} \mathrm{C}$ and at night $23{ }^{\circ} \mathrm{C}$.

\section{Material and methods}

Bark samples from living trees and litter samples (mostly fallen leaves) for moist chamber cultures were collected from Dar es Salaam, from the garden of the Finnish Village in Oyster Bay, at the end of the cape Msasani. The material was placed in clean paper bags which were sealed with adhesive tape during transportation. The cultures were prepared in Finland six weeks later. Bark and litter pieces were placed with forceps in sterile Petri dishes $(9.5 \mathrm{~cm}$ diam.) on a filter paper as a single layer covering the bottom. The forceps were first washed in distilled water, dried with a clean piece of paper and then sterilized in ethanol before each individual use. The dishes were filled with distilled water adjusted to $\mathrm{pH} 7.0$ with $\mathrm{KOH}$, and the covers replaced. After 24 hours the $\mathrm{pH}$ of the water was measured with a $\mathrm{pH}$ meter (Whatman PHA 300) and with pH strips (Merk Universalindikator). 
After this, some of the water was poured off. Next day the $\mathrm{pH}$ of the remaining water was measured again with $\mathrm{pH}$ strips. The cultures were incubated in normal room conditions (circa $20^{\circ} \mathrm{C}$ ) in diffuse day light and examined under a dissecting microscope at least every second day for four weeks. If necessary, some more water was added during the incubation. When developing myxomycetes emerged, the $\mathrm{pH}$ was measured once more and the lid of the Petri dish was left slightly ajar, so the culture dried slowly. Chambers that produced no myxomycetes, or in which plasmodia did not form mature fructifications, were dried for five weeks. After this they were rewetted for another four week incubation period. The cultures that had produced myxomycetes were rewetted after picking out the pieces having myxomycetes.

When representatives of a species appeared twice in the same Petri dish they were counted as one specimen.

\section{List and description of myxomycete species}

From the 16 moist chamber cultures 27 specimens emerged. They represent 19 species in 7 genera. Four species have not been reported from Tanzania previously: Licea kleistobolus, Physarum echinosporum, P. oblatum, and P. spumarioides var. degawae. The last mentioned species is reported for the first time from Africa.

The species are listed below in systematical order according to Nannenga-Bremekamp (1991); species are listed alphabetically within each genus. Species new to Tanzania are described in detail. Descriptions are based on the Tanzanian material (including the material collected from the Usambara mountains, Ukkola 1998). TU refers to the collections of the author. The other species in the list have been described in previous publications of Tanzanian myxomycetes (see Härkönen and Saari-mäki 1991, Ukkola et al. 1996). Physarum leucophaeum Fr., although not new to Tanzania, is also described below. Eichelbaum (1906) has reported it from the East Usambara mountains, but has provided the identification with a question mark and with no detail description. Specimens are deposited at the Botanical Museum of the University of Helsinki (H).

\section{Licea biforis Morgan}

Material examined: Tanzania. Eastern Prov.: Dar es Salaam, Oyster Bay, Finnish Village, on reed of living Bambusa sp. and on bark of Plumeria alba, 06.XII.1995 TU 201, 205.

Licea biforis grew mixed with Calomyxa metallica (Berk.) Nieuwl., Licea kleistobolus,
Licea sp., and Physarum pusillum (Berk. \& M. A. Curtis) G. Lister.

Licea kleistobolus G. W. Martin - Fig. 1

Material examined: Tanzania. Eastern Prov.: Dar es Salaam, Oyster Bay, Finnish Village, on bark of living Azadirachta indica and Plumeria alba, 06.XII. 1995, TU 198, TU 202. Earlier records from Africa are from Tunisia (Mitchell \& Kylin 1984), Nigeria (Ejale \& Gill $1991)$ and from the Canary Islands (Champion \& Beltrán Tejera 1980). New to Tanzania.

Sporangia scattered or gregarious, sessile, circular or oval in outline, discoid, brown to dark brown; 0.08-0.12 mm diam.; opening with a flat, shiny operculum. Peridium thin, brown, the basal part covered with waste deposits, upper margin lined with small tubercles; operculum thin, shiny yellow-brown to copper brown in reflected light, nearly hyaline in transmitted light, the inside punctate and with distinct, hollow papillae. Spores ochraceous in

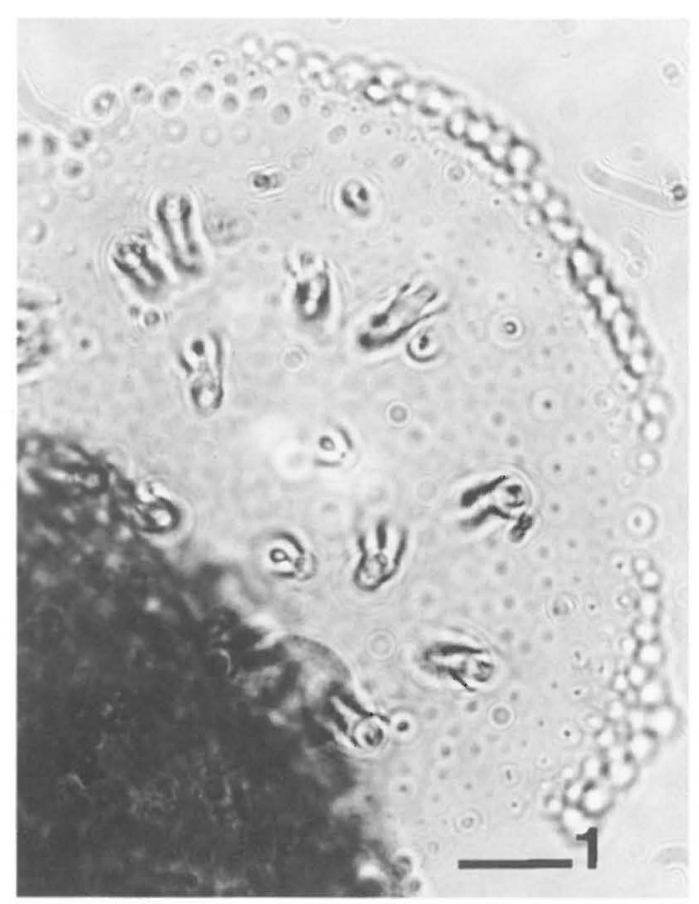

Fig.1. Licea kleistobolus (TU 290, a specimen from the Usambara Mts.). Part of a sporangium and the detached, warted lid with distinct margin and large, hollow papillae. $\mathrm{Bar}=10 \mu \mathrm{m}$. 
mass, pale yellowish to nearly hyaline in transmitted light, globose, thin-walled; ornamented with scatterd groups of spines, 8- $\underline{9.2-10.5 \mu \mathrm{m}}$ diam.

The description includes also a specimen collected from the Usambara mountains, NE Tanzania in December 1995 (Ukkola 1998). Specimens from Dar es Salaam grew mixed with Calomyxa metallica, Licea biforis, Licea parasitica (Zukal) G. W. Martin, and Licea sp.

According to Gilert $(1985,1996)$, processes emerging from the inner surface of the lid of $\mathrm{Li}$ cea kleistobolus (Fig. 1) "represent different stages in the development or reduction of a capillitium", the shape and morphology of which is close to that of Perichaena species, in particular species with poorly developed capillitium (Gilert 1996).

\section{Licea parasitica (Zukal) G. W. Martin}

Material examined: Tanzania. Eastern Prov.: Dar es Salaam, Oyster Bay, Finnish Village, on bark of living Azadirachta indica, 06.XII.1995, TU 197.

The specimen grew mixed with Calomyxa metallica and Licea kleistobolus.

\section{Licea sp. - Figs. 2-5}

Material examined. Tanzania. Eastern Prov.: Dar es Salaam, Oyster Bay, Finnish Village, on bark of living Plumeria alba, 06.XII.1995, TU 200.

Sporangia scattered, stipitate or occasionally nearly sessile, globose to subglobose, dark brown to nearly black; total height (100-)140$300 \mu \mathrm{m}, 80-150 \mu \mathrm{m}$ diam. Stalk stout, about one third to one half of the total height, occasionally very short; deeply furrowed, dark brown, reddish brown in transmitted light, filled with refuse matter. Hypothallus inconspicuous. Peridium wrinkled, covered with refuse, granular matter arranged in patches, especially on the upper part; outer peridium somewhat shiny, inner layer thin, smoky brown in transmitted light, densely and minutely warted, warts partially arranged in rows; upper part of peridium dehiscing into irregular plates, basal part persisting as a cup. Spores dark brown in mass, olive brown in transmitted light, globose, smooth (also in SEM), thick-walled with a distinct thinner, paler area, 9-9.4-10 $\mu \mathrm{m}$ diam. Plasmodium not observed.
This Licea species is not named, since the description is based on only one specimen, developed in a moist chamber culture. The attempt to cultivate this species on oat and corn agar was not successful. The spores did not germinate. The specimen grew mixed with Calomyxa metallica, Licea biforis, and L. kleistobolus.

A Licea specimen earlier reported from Tanzania (Ukkola et al. 1996) (western foot of Mt. Meru, alt. 1830, on bark of Cupressus lusitanica, mc MH 3594) as Licea cf. pedicellata possibly belongs to the same species as the present one. Licea pedicellata (H. C. Gilbert) H. C. Gilbert has smooth or finely warted spores, 12-13 $\mu \mathrm{m}$ in diam. (Gilbert 1934). The type specimen of L. pedicellata (Gilbert No. 2117, Milford, Iowa, July 16, 1932), studied previously by the author (see Ukkola et al. 1996), has yellowish brown, faintly warted spores. The spores of the present Tanzanian Licea specimen are olive brown in transmitted light and smooth (Figs. 45). The specimen is also very close to Licea rugosa Nann.-Bremek. \& Y. Yamam., which has darker and larger spores, 15-16 $\mu \mathrm{m}$ diam. (Nannenga-Bremekamp and Yamamoto 1987). The slide of the type specimen of Licea rugosa has also been studied previously by the author (Ukkola et al. 1996).

\section{Calomyxa metallica (Berk.) Nieuwl.}

Material examined: Tanzania. Eastern Prov.: Dar es Salaam, Oyster Bay, Finnish Village, on bark of living Azadirachta indica and Plumeria alba, 06.XII.1995, TU 199, 203.

The specimens grew together with Licea biforis, L. kleistobolus, L. parasitica, and Licea sp.

\section{Perichaena chrysosperma (Curr.) Lister}

Material examined: Tanzania. Eastern Prov.: Dar es Salaam, Oyster Bay, Finnish Village, on bark of living Ficus sycomorus and on fallen leaves of Ficus benjamina, 06.XII.1995, TU 191, 211.

The specimens grew mixed with Arcyria minuta Buchet, Perichaena depressa Lib., and Physarum diderma Rostaf.

This species is earlier collected in Tanzania from submontane belt, alt. 800-900 m, growing on wood (Eichelbaum 1906) and on bark (in moist chamber culture) of living Juniperus 


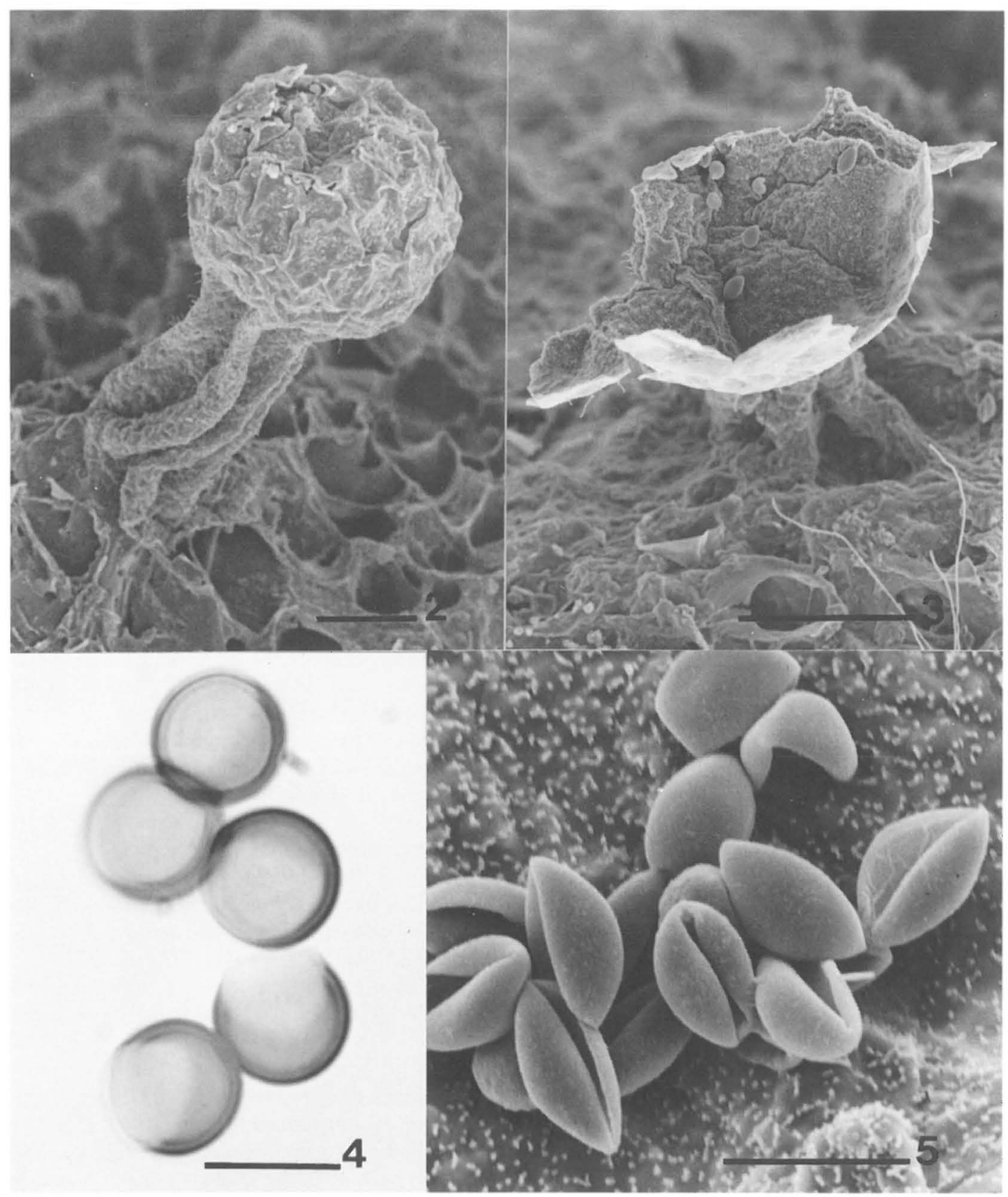

Figs. 2-5. Scanning electron micrographs and a compound microscopic photo of Licea sp. (TU 200). - 2: A whole sporangium. Bar $=50 \mu \mathrm{m}$. 3: A dehiscent sporangium. Bar $=50 \mu \mathrm{m}$. 4: Some spores in light microscope. Bar $=10 \mu \mathrm{m}$. 5: Part of warted inner peridium and some collapsed spores, smooth in SEM. Bar $=10 \mu$. 
procera (Ukkola et al. 1996). In the latter case it grew also together with Perichaena depressa and Physarum diderma.

Perichaena corticalis (Batsch) Rostaf.

Material examined. Tanzania. Eastern Prov: Dar es Salaam, Oyster Bay, Finnish Village, on dead leaves of Bambusa sp., 06.XII.1995, TU 216.

The specimen grew mixed with Physarum spumarioides var. degawae.

In an earlier report on Tanzanian myxomycetes (Ukkola et al. 1996) the spore diameter was reported to be $9-10.8-11 \mu \mathrm{m}$. In this specimen the spores were larger, 11.5-12.8-14 $\mu \mathrm{m}$ diam.

Perichaena corticalis often occurs on bark, less commonly on plant debris. Faurel and Schotter (1965) have reported it from the Congo on gazelle dung, Rammeloo and Mitchell (1994) from Malawi on rotten leaves of Helichrysum.

\section{Perichaena depressa Lib.}

Material examined. Tanzania. Eastern Prov.: Dar es Salaam, Oyster Bay, Finnish Village, on bark of living Ficus sycomorus and fallen leaves of Ficus benjamina, 06.XII.1995, TU 190, 210. Perichaena depressa grew mixed with Arcyria minuta, Perichaena chrysosperma, and Physarum diderma.

The species is earlier reported from Tanzania on decayed wood (Eichelbaum 1906) and on bark (in moist chamber) of living Juniperus procera. It is less common on leaves and other plant debris (Martin \& Alexopuolos 1969). Malençon and Bertault (1967) have reported it from Morocco on leaves of Eucalyptus, Eliasson (1991) from the Hawaiian Islands on a decaying palm leaf and on various debris in the litter layer, and Rammeloo and Mitchell (1994) from Malawi on rotten leaves of Helichrysum and Digitalis.

Arcyria cinerea (Bull.) Pers.

Material examined: Tanzania. Eastern Prov,: Dar es Salaam, Oyster Bay, Finnish Village, on bark of living Pithecellobium dulce, 06.XII.1995, TU 193.

Arcyria cinerea grew mixed with Diderma hemisphaericum (Bull.) Hornem. and Physarum echinosporum.
Arcyria minuta Buchet

Material examined: Tanzania. Eastern Prov.: Dar es Salaam, Oyster Bay, Finnish Village, on bark of living Ficus sycomorus, 06.XII.1995, TU 189.

The specimen grew together with Perichaena chrysosperma, P. depressa, and Physarum diderma.

\section{Physarum crateriforme Petch}

Material examined: Tanzania. Eastern Prov.: Dar es Salaam, Oyster Bay, Finnish Village, on bark of living Sideroxylon inerme, 06.XII.1995, TU 196.

\section{Physarum diderma Rostaf.}

Material examined: Tanzania. Eastern Prov.: Dar es Salaam, Oyster Bay, Finnish Village, on bark of living Ficus sycomorus, 06.XII.1995, TU 192.

Mixed with Arcyria minuta, Perichaena crysosperma and $P$. depressa.

\section{Physarum echinosporum Lister}

Material examined: Tanzania. Eastern Prov.; Dar es Salaam, Oyster Bay, Finnish Village, on bark of living Pithecellobium dulce, 06.XII.1995, TU 195. Previous records from Africa are from Angola, Mozambique (Almeida 1973, 1974), Kenya (Martin \& Alexopoulos 1969) and from the Canary Islands (Beltrán Tejera \& Mosquera 1996). New to Tanzania.

Fructifications scattered or gregarious; sessile, clam-shaped, reniform or clavate sporangia, $0.2-1 \mathrm{~mm}$ diam., $0.3-0.7 \mathrm{~mm}$ tall, or curved plasmodiocarps up to $3 \mathrm{~mm}$ long; strongly compressed laterally, white. Peridium double, outer layer smooth, brittle, egg shell-like, occasionally faintly wrinkled, brownish at the base; inner layer membranous, translucent, iridescent, easily separable from the outer layer; dehiscence by a fissure along the upper margin. Columella none. Capillitium consisting of short, hyaline threads, connected with large, elongate or rounded white lime nodes. Spores black in mass, dark brown in transmitted light, globose, ornamented with prominent spines which sometimes unite as short ridges, 9-9.4-10 $\mu \mathrm{m}$ diam. without the up to $1 \mu \mathrm{m}$ long spines. Plasmodium not observed.

Mixed with Arcyria cinerea and Diderma hemisphaericum. 


\section{Physarum leucophaeum Fr.}

Material examined: Tanzania. Eastern Prov.: Dar es Salaam, Oyster Bay, Finnish Village, on litter of Musa sp., 06.XII.1995, TU 212. Eichelbaum (1906) has reported this species (with a question mark) from the East Usambara Mountains growing on living leaves. Other records from Africa are from northern parts (Maire et al. 1926, Faurel et al. 1965, Malençon \& Bertault 1969, Mitchell and Kylin 1984), Sierra Leone (Ing 1967), South Africa (Duthie 1917a, 1917b, Doidge 1950) and from the Canary Islands (Champion \& Beltrán Tejera 1980, Bañares Baudet et al. 1986).

Sporangia scattered or loosely crowded, stipitate or nearly sessile, erect, globose to subglobose with a flat base, sometimes slightly reniform; white to greyish white; up to $1 \mathrm{~mm}$ tall, $0.15-0.5 \mathrm{~mm}$ diam. Stalk short, up to half the total height, rarely longer, erect, furrowed, tapering upwards; red brown to dark brown, yellowish red-brown or ochraceous in transmitted light, with refuse matter. Hypothallus brown, membranous or inconspicuous. Peridium membranous, translucent, covered with white lime flakes and /or ridges, or limeless and dark at the base; lime in some sporangia scanty and peridium shiny. Columella short, conical, dark brown or absent. Capillitium consisting of thin, hyaline threads forming a net, threads connected with usually numerous, white, rounded or irregularly shaped lime nodes. Spores dark brown in mass, brown to light brown in transmitted light, globose to subglobose, minutely warted with groups of darker warts, (8-)9-10-11.5 $\mu \mathrm{m}$ diam. Plasmodium yellowish.

The description includes also three specimens ( $T U 232,278,346 A$ ) collected from the Usambara mountains, NE Tanzania in December 1995 (Ukkola 1998).

Sporangia are fairly small. The dimensions given in the literature are larger: $0.4-0.8 \mathrm{~mm}$ diam., total height 0.8-1.5(-2) mm (Farr 1976, Martin \& Alexopoulos 1969, NannengaBremekamp 1991, Neubert et al. 1995).

\section{Physarum oblatum T. Macbr.}

Material examined: Tanzania. Eastern Prov.: Dar es Salaam, Oyster Bay, Finnish Village, on bark of living Thevetia peruviana, 06.XII.1995, $T U$ 188. An earlier record from Africa is from Nigeria (Ing 1964). New to Tanzania.
Sporangia scattered, gregarious or grouped 2-6; globose, depressed globose or slightly pyriform, yellow, ochraceous or greenish yellow, sometimes fading to nearly white; $0.5-1.2 \mathrm{~mm}$ tall, $0.25-0.40 \mathrm{~mm}$ diam. Stalk about half to nearly two thirds of the total height, longitudinally furrowed, occasionally laterally depressed, red brown and translucent to dark brown or nearly black, darker and somewhat thicker at the base, red brown in transmitted light, with refuse matter. Hypothallus membranous, brown to dark brown, separate or common to a group. Peridium membranous above, usually thickly covered with yellow, ochraceous or greenish yellow or nearly white lime granules, red or dark brown and often thickened at the base; dehiscence into irregular lobes or in a floriform fashion at the upper part. Columella none. Capillitium of thin, hyaline threads, connected with yellow, pale yellow or white, variously shaped and sized lime nodes. Spores dark brown to blackish brown in mass, pale brown to brown in transmitted light, globose, minutely warted, with clusters of darker warts, 8-9.3-10 $\mu \mathrm{m}$ diam. Plasmodium yellow to greenish yellow.

The description includes also three specimens ( $T U$ 337, 353, 392) obtained from the Usambara mountains in December 1995 (Ukkola 1998).

\section{Physarum pusillum (Berk. \& M. A. Curtis) G. Lister}

Material examined: Tanzania. Eastern Prov.: Dar es Salaam, Oyster Bay, Finnish Village, on reed of living Bambusa sp., 6 Dec.1995, TU 206. Mixed with Licea biforis.

Physarum spumarioides T.N. Lakh. \& Mukerji var. degawae Nann.-Bremek. \& Y. Yamam. Figs 6-7

Material examined: Tanzania. Eastern Prov.: Dar es Salaam, Oyster Bay, Finnish Village, on dead leaves of Bambusa sp., Ficus sycomorus, Plumeria alba, and Thevetia peruviana, 06.XII.1995, TU 207, 208, 213, 215. Physarum spumarioides var. spumarioides has been described from India (Lakhanpal \& Mukerji 1981); var. degawae from Japan (NannengaBremekamp \& Yamamoto 1990). New to Africa.

Fructifications plasmodiocarpous and/or sessile, densely crowded, heaped and contorted 


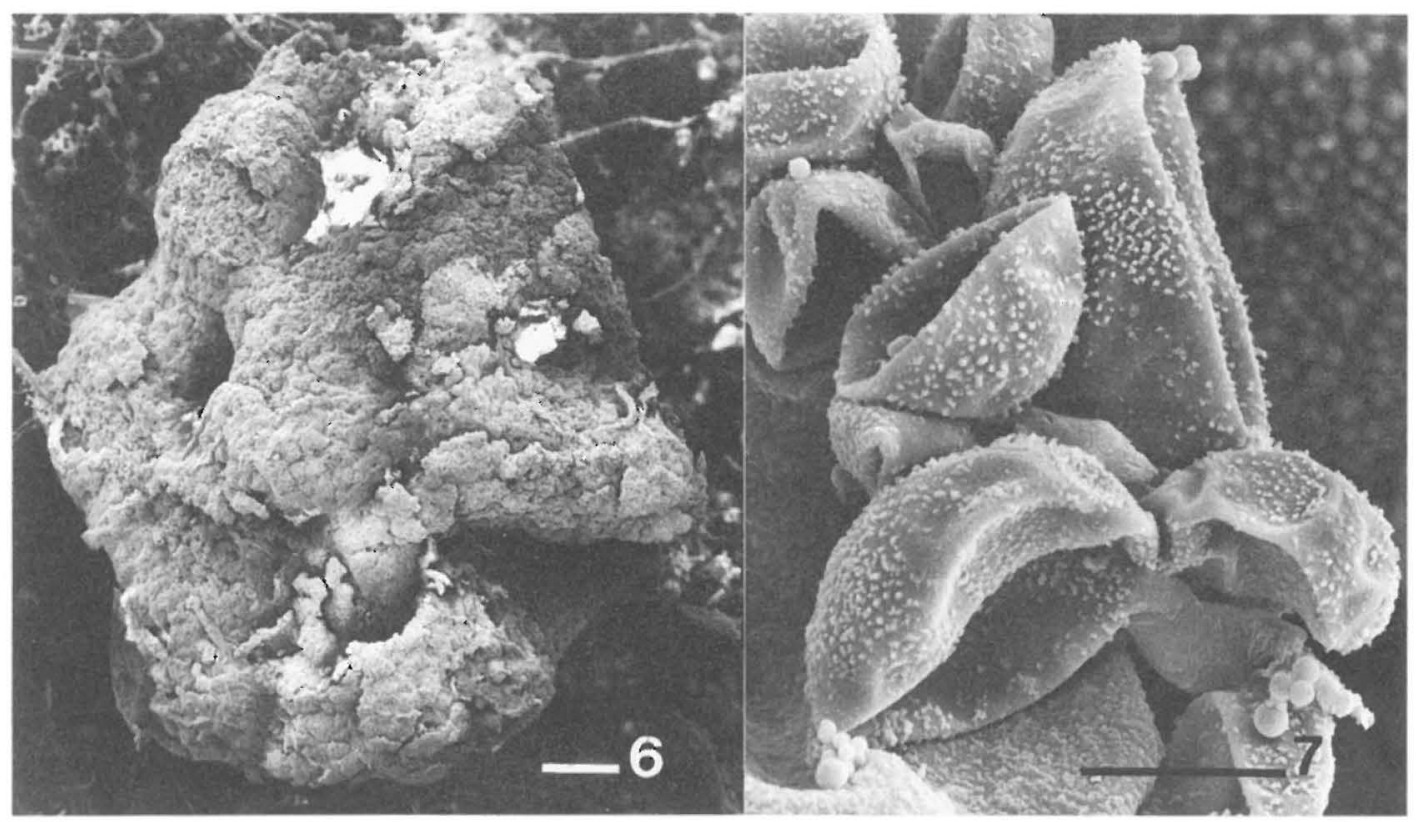

Figs. 6-7. Scanning electron micrographs of Physarum spumarioides var. degawae (TU 213). 6: Fructification forming a pseudoaethalioid mass. Bar $=100 \mu \mathrm{m}$. 7: Some collapsed, warted spores. Bar $=10 \mu \mathrm{m}$.

sporocarps, $1-3 \times 0.5-2 \mathrm{~mm}$ in diameter, $0.5-$ $1.2(-1.8) \mathrm{mm}$ high, often forming a pseudoaethalioid mass up to $6 \mathrm{~mm}$ diam. and $3 \mathrm{~mm}$ high, with some solitary, sessile, globose to somewhat prolate sporangia, $0.5-1 \mathrm{~mm}$ diam; white to greyish white, greyish brown and iridescent if lime is absent. Hypothallus extensive, cremewhite, common to a group, occasionally, in solitary sporangia, somewhat prolate. Peridium usually densely covered with white lime scales and dots, often partially agglutinated into plates, making the peridium appearing double; dehiscence irregular. Columella none, very rarely with a small, irregularly shaped pseudocolumella. Capillitium abundant, consisting of thin, short, hyaline threads, connected with many white, variously sized, angular or prominently elongate lime nodes; capillitium sometimes somewhat badhamioid. Spores black in mass, dark brown in transmitted light, globose, subglobose or broadly elliptical, minutely warted, $9-\underline{10}-11 \mu \mathrm{m}$ or $9-\underline{9.3}-10 \times 10.5-\underline{11.5}-12.5$ $\mu \mathrm{m}$ diam. Plasmodium pale brownish.
The Tanzanian material has somewhat smaller spores than in the description of Physarum spumarioides var. degawae (12-14 $(-15) \mu \mathrm{m} / 10-12 \times 12-14(-15) \mu \mathrm{m})$ and the capillitium is in some sporangia somewhat badhamioid, which is usually not the case with var. degawae (Nannenga-Bremekamp \& Yamamoto 1990). Physarum spumarioides var. spumarioides has a badhamioid capillitium, which, however, is scanty. This variety is primarily sporangiate, it has a distinct pseudocolumella and the spores are globose with warts arranged in conspicuous lines (Lakhanpal \& Mukerji, 1981). The Tanzanian specimens seem to be intermediate between these two varieties, but are closer to var. degawae. The identity of specimen TU 207 was confirmed by Y. Yamamoto.

Greyish white fructifications of Physarum gyrosum Rostaf. may macroscopically look very similar to the Tanzanian material. The sporocarps of $P$. gyrosum are, however, often somewhat brownish, reddish or rosy-grey (Martin \& Alexopoulos 1969, Nannenga-Bremekamp 
1991, Neubert et al. 1995). Some capillitial lime nodes are small, fusiform and some are large, spike-like, reaching almost from wall to wall. Spores are globose, paler and slightly smaller $(7-10 \mu \mathrm{m})$. The plasmodiocarpous fructifications of the studied material, may approach Physarum vernum Sommerf., but this species does not form a pseudoaethalioid mass. It is also considered to be primarly mountaneous and has been reported from Tanzania from Mt. Meru and from South Pare mountains (Ukkola et al. 1996).

Specimen TU 215 grew mixed with Perichaena corticalis.

Diderma hemisphaericum (Bull.) Hornem.

Material examined: Tanzania. Eastern Prov.: Dar es Salaam, Oyster Bay, Finnish Village, on bark of living Pithecellobium dulce, 06.XII.1995, TU 194. Mixed with Arcyria cinerea and Physarum echinosporum.

Didymium squamulosum (Alb. \& Schwein.) Fr. Material examined: Tanzania. Eastern Prov.: Dar es Salaam, Oyster Bay, Finnish Village, on dead leaves of Pithecellobium dulce, 06.XII.1995, TU 209.

\section{Discussion}

Altogether, 27 specimens and 19 species from 16 moist chamber cultures emerged (Fig. 8). Moist chamber cultures with bark of living trees produced 18 specimens which represent 15 species of six genera. From litter cultures 9 specimens developed, representing 6 species of three genera.

Arcyria cinerea, Calomyxa metallica, Diderma hemisphaericum, Perichaena species, Physarum diderma, and P. echinosporum did not emerge until the second incubation period, after five weeks in dryness.

The $\mathrm{pH}$ values of bark did not change significantly during the four weeks of incubation. However, after drying for five weeks, the substrata were somewhat more acid than at the beginning of the first incubation period in every moist chamber culture prepared with bark of living trees. Härkönen (1977) has studied corticolous myxomycetes in southern Finland, and in that study no noteworthy changes of $\mathrm{pH}$ were recorded during incubation or after two weeks of dryness. In the present study the largest change was from $\mathrm{pH} 6.6$ to 5.2 in bark of $\mathrm{Aza}$ dirachta indica. In this culture the $\mathrm{pH}$ value also changed during the first incubation period, from 6.6 to about 6.0. The culture produced $\mathrm{Li}$ cea kleistobolus and L. parasitica during the first incubation period; Calomyxa metallica developed after drying and rewetting. The influence of the dry period on the $\mathrm{pH}$ values was less distinct in moist chamber cultures prepared with litter, and the changes, if any, were usually in the opposite direction. In litter cultures with $\mathrm{pH}$ values of 5.5 to 6.0 the $\mathrm{pH}$ changed slightly also during the incubation, to neutral or nearly neutral.

Arcyria cinerea, Diderma hemisphaericum, and Physarum echinosporum grew on most acid substrata (pH 5.2-5.7) (Fig. 8). Arcyria minuta, Didymium squamulosum, Perichaena species, Physarum diderma, and P. leucophaeum preferred neutral or nearly neutral substrata. Physarum spumarioides var degawae had a relatively wide $\mathrm{pH}$ tolerance, 5.9-7.9, growing in one culture (on dead leaves of Ficus sycomorus) on slightly alkaline substratum.

Bark of living trees seemed to be a favourable substrate for myxomycetes in tropical lowlands, although the number of moist chamber cultures prepared in this study is so small that no general conclusions can be made. Only one bark culture (with Gmelina arborea) did not produce any myxomycetes. The others were very productive, in one culture (bark of Ficus sycomorus) producing four species of myxomycetes.

Litter cultures were also productive, myxomycetes grew in seven litter cultures of the eight prepared. A phaneroplasmodium grew on dead leaves of Nerium oleander, but it failed to sporulate during both incubation periods. Two cultures (dead leaves of Bambusa sp. and Ficus sycomorus) produced two species, the others only one.

This small study of the myxomycetes in Dar es Salaam supports the previous results we have obtained from moist chamber cultures, which were prepared with material collected from lowland and submontane belt in Tanzania (Ukkola et al. 1996). They indicate that slime moulds probably are not so rare in tropical areas, not even in lowlands, as previously believed (see e.g. Alexopoulos 1970, Farr 1976). 


\section{Substratum pH of the Incubation Tree/Plant species substratum time in days}

\section{Myxomycete species}

$\begin{array}{llccl}\text { Arcyria cinerea } & \text { bark } & 5.2-5.7 & 21 & \text { Pithecellobium dulce } \\ \text { A. minuta } & \text { bark } & 7.0-7.1 & 8 & \text { Ficus sycomorus } \\ \text { Calomyxa metallica } & \text { bark } & 5.2-6.6 & 17 & \text { Azadirachta indica } \\ & \text { bark } & 6.0-6.7 & 7 & \text { Plumeria alba } \\ \text { Diderma hemisphaericum } & \text { bark } & 5.2-5.7 & 24 & \text { Pithecellobium dulce } \\ \text { Didymium squamulosum } & \text { dead leaves } & 7.0-7.1 & 9 & \text { Pithecellobium dulce } \\ \text { Licea biforis } & \text { bark } & 6.0-6.7 & 4-7 & \text { Plumeria alba } \\ & \text { reed } & 6.1-6.9 & 4-6 & \text { Bambusa sp. } \\ \text { L. kleistobolus } & \text { bark } & 5.2-6.6 & 13 & \text { Azadirachta indica } \\ & \text { bark } & 6.0-6.7 & 13 & \text { Plumeria alba } \\ \text { L. parasitica } & \text { bark } & 5.2-6.6 & 7 & \text { Azadirachta indica } \\ \text { Licea sp. } & \text { bark } & 6.0-6.7 & 7 & \text { Plumeria alba } \\ \text { Perichaena chrysosperma } & \text { bark } & 6.5-7.1 & 21 & \text { Ficus sycomorus } \\ & \text { dead leaves } & 7.0-7.3 & 4 & \text { Ficus benjamina } \\ \text { P. corticalis } & \text { dead leaves } & 6.5-7.0 & 7 & \text { Ficus benjamina } \\ \text { P. depressa } & \text { bark } & 6.5-7.1 & 14 & \text { Ficus sycomorus } \\ & \text { dead leaves } & 7.0-7.3 & 23 & \text { Ficus benjamina } \\ \text { Physarum crateriforme } & \text { bark } & 6.1-6.9 & 4-8 & \text { Sideroxylon inerme } \\ \text { P. diderma } & \text { bark } & 6.5-7.1 & 32 & \text { Ficus sycomorus } \\ \text { P. echinosporum } & \text { bark } & 5.2-5.7 & 24 & \text { Pithecellobium dulce } \\ \text { P. leucophaeum } & \text { litter } & 7.0 & 16-22 & \text { Musa sp. } \\ \text { P. oblatum } & \text { bark } & 5.8-6.3 & 8-10 & \text { Thevetia peruviana } \\ \text { P. pusillum } & \text { reed } & 6.1-6.9 & 4-8 & \text { Bambusa sp. } \\ \text { P. spumarioides var. degawae } & \text { dead leaves } & 6.6-7.0 & 16 & \text { Bambusa sp. } \\ & \text { dead leaves } & 7.3-7.9 & 5-16 & \text { Ficus sycomorus } \\ & \text { dead leaves } & 5.9-6.5 & 5-16 & \text { Plumeria alba } \\ & \text { dead leaves } & 6.1-7.0 & 6-20 & \text { Thevetia peruviana }\end{array}$

Fig. 8. Myxomycete species obtained in moist chamber cultures prepared from material collected in Dar es Salaam.

Härkönen (1981) has also obtained good results from Gambia. Eighty-three specimens of myxomycetes developed from 117 moist chamber cultures prepared with plant remains and bark from living trees collected from lowland savanna regions.

The number of myxomycetes reported from Tanzania now comprises 96 identified species.

Acknowledgments. I wish to thank Mr.Yukinori Yamamoto for confirming the identity of Physarum spumarioides var. degawae. I am grateful to Dr. Tuomo Niemelä, Leo Junikka, Lic.Phil., Leif Schulman, MSc., and
Kari Lahti, MSc. for the identification of the tree species. I thank the Academy of Finland and the University of Helsinki for financial support.

\section{References}

Alexopoulos, C.J. 1970: Rain forest Myxomycetes. In: Odum, H. (ed.), A tropical rain forest, pp. 21-23. U.S. Atomic Energy Commission.

Almeida, M.G. 1973: Contribuição para o conhecimento dos Myxomycetes de Angola 1. - Bol. Soc. Broteriana 47:277-297. 
Almeida, M.G. 1974: Contribuição para o conhecimento dos Myxomycetes de Moçambique. - Bol. Soc. Broteriana 48:205-210.

Bañares Baudet, A., Beltran Tejera, E. \& Wildpret de la Torre, W. 1986: Contribución al estudio micológico de los pinares de Tamadaba (Gran Canaria). II. Myxomycota, Ascomycotina y Basidiomycotina (Tremellales y Aphyllophorales). - Vierea 16:119-135.

Beltrán Tejera, E. \& Mosquera, J. 1996: Myxomycetes de las Islas Canarias. Adiciones corológicas de interés. In: Lado, C. \& Hernández. J.C. (eds.), Second International Congress on the Systematics and Ecology of Myxomycetes, p. 82. - Abstract Volume, Madrid. $144 \mathrm{pp}$.

Champion, C.L. \& Beltrán Tejera, E. 1980: Catálogo preliminar de los Myxomycetes de Canarias. - Vierea 9:153-182.

Doidge, E. M. 1950: The South African fungi and lichens to the end of 1945. - Bothalia 5:1-1094.

Duthie, A.V. 1917a: South African Myxomycetes. - S. African J. Sci. 14:456-460.

Duthie, A.V. 1917b: African Myxomycetes. - Trans. Roy. Soc. S. Africa 6:297-310.

Eichelbaum, F. 1906: Beiträge zur Kenntnis der Pilzflora des Ostusambaragebirges. - Verh. Naturwiss. Ver. Hamburg 3. (14):1-92.

Ejale, A. \& Gill. L. 1991: Identification of Myxomycetes (Order Liceales) from Bendel State, Nigeria - II. - Korean J. Mycol. 4:250-252.

Eliasson, U.H. 1991: The myxomycete biota of the Hawaiian Islands. - Mycol. Res. 95:257-267.

Farr, M.L. 1976: Myxomycetes. - Flora Neotropica Monogr. 16:1-304.

Faurel. L., Feldmann, J. \& Schotter, G. 1965: Catalogue des Myxomycètes de 1'Afrique du Nord. - Bull. Soc. Hist. Nat. Afrique Nord 55:7-35.

Faurel, L. \& Schotter, G. 1965: Notes Mycologiques 6. Sur quelques Champignons coprophiles d'Afrique Equatoriale. - Cah. Maboké 3:123-132

Gilbert, H.C. 1934: Three new species of Myxomycetes. - Univ. Iowa Stud. Nat. Hist. 16:153-159.

Gilert, E. 1985: Ultrastructure of Licea kleistobolus (Myxomycetes) and its bearing on the taxonomic affinity of the species. - Nord. J. Bot. 5:99-104.

Gilert, E. 1996: Morphological and ultrastructural features in selected species of Licea (Myxomycetes). Nord. J. Bot. 16:515-547.

Härkönen, M. 1977: Corticolous Myxomycetes in three different habitats in southern Finland. - Karstenia 17:19-32.

Härkönen, M. 1981: Gambian Myxomycetes developed in moist chamber cultures. - Karstenia 21:21-25.

Härkönen, M. \& Saarimäki, T. 1991: Tanzanian Myxomycetes: first survey. - Karstenia 31:31-54.

Ing, B. 1964: Myxomycetes from Nigeria. - Trans. British Mycol. Soc. 47:49-55.

Ing, B. 1967: Myxomycetes from Sierra Leone. - Trans. British Mycol. Soc. 50:549-553.

Lakhanpal, T.N. \& Mukerji, K.G. 1981: Taxonomy of the Indian Myxomycetes. - Bibl. Mycol. 78:1-530. J. Cramer, Vaduz.

Maire, R., Patouillard, N. \& Pinoy, E. 1926: Myxomy-

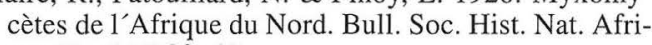
que Nord 17:38-43.
Malençon, G. \& Bertault, R. 1967: Champignons du Maroc. - Bull. Soc. Sci. Nat. Phys. Maroc 47:237281.

Malençon, G. \& Bertault, R. 1969: Champignons du Maroc 2. - Bull. Soc. Sci. Nat. Phys. Maroc 49:69-80.

Martin, G.W. \& Alexopoulos, C.J. 1969: The Myxomycetes. -560 pp. Univ. of Iowa Press, Iowa City.

Mitchell, D.W. \& Kylin, H. 1984: Some Tunisian Myxomycetes. - Bull. British Mycol. Soc. 18:64-65.

Nannenga-Bremekamp, N.E. 1991: A guide to temperate Myxomycetes. - 409 pp. Biopress, Bristol. (English translation by A. Feest and Y. Burggraaf of De Nederlandse Myxomyceten. - 460 pp. Kon. Nederlandse Nat. Ver., Zutphen).

Nannenga-Bremekamp, N.E. \& Yamamoto, Y. 1987: Additions to the Myxomycetes of Japan 3. - Proc. Kon. Nederlandse Akad. Wetensch. C. 90:311-349.

Nannenga-Bremekamp, N.E. \& Yamamoto, Y. 1990: Additions to the Myxomycetes of Japan 4. - Proc. Kon. Nederlandse Akad. Wetensch. C 93:265-280.

Neubert, H., Nowotny, W. \& Bauman, K. 1995: Die Myxomyceten Deutschlands und des angrenzenden Alpenraumes unter besonderer Berücksichtigung Österreichs 2. Physarales. - 368 pp. Karlheinz Bauman Verlag, Gomaringen.

Polhill, D. 1988: Flora of East Tropical Africa. Index of collecting localities. - 398 pp. Royal Bot. Gardens, Kew.

Rammeloo, J. \& Mitchell, D.W. 1994: Contribution towards the knowledge of the Myxomycetes of Malawi and Zambia. - J. H. Seyani \& A. C. Chikuni, Proc. XIII Plenary Meeting AETFAT, Malawi, 1:785-793.

Ukkola, T. 1998: Myxomycetes of the Usambara Mountains, NE Tanzania. - Acta Bot. Fennica. 160:1-37.

Ukkola, T. \& Härkönen, M. 1996: Revision of Physarum pezizoideum var. pezizoideum and var. microsporum (Myxomycetes). - Karstenia 36:41-46.

Ukkola, T., Härkönen, M. \& Saarimäki, T. 1996: Tanzanian Myxomycetes: second survey. - Karstenia 36:5177.

Received on 7 August 1977 